\title{
DIGITAL MARKETING IN THE PRACTICE OF SMALL AND MEDIUM ENTERPRISES IN THE REPUBLIC OF MOLDOVA
}

\author{
Valeri GAGAUZ1, PhD Student, \\ Academy of Economic Studies of Moldova
}

\author{
DOI: https://doi.org/10.36004/nier.es.2020.1-06 \\ JEL Classification: Q3, M, MO, M3, M31 \\ UDC: 339.138:004.738.5
}

\begin{abstract}
The use of modern marketing strategies for small and medium-sized enterprises (SMEs) is an important factor that can contribute to strengthening entrepreneurial activity, qualitative structural changes to SMEs, and ensuring business sustainability and stability. The digital revolution and technologies open up new opportunities for the business sector, improving the quality of communication with customers, while digital marketing (DM) is an important tool that can ensure the competitiveness and effectiveness of actions taken to promote products and services. This article presents the results of a qualitative study of the perception and practice of SMEs in the field of DM conducted by the author in 2019. Twenty entrepreneurs - SME owners in Chisinau were interviewed. The analysis also includes a case study of the BRAVO-MOTORS company practice. The theoretical and conceptual framework of the study is comprised of modern marketing theory, ResourceBased View approach (Wernerelt B.) and Theory of dynamic capabilities (Teece et al.). The results of the study showed that SMEs do not pay due attention to digitalization of business processes, data collection and analysis, optimization of work processes and monitoring of key indicators. The role and importance of developing a marketing strategy is in many cases underestimated, and marketing activities are limited to the use of individual marketing elements only. There is a low level of competence of entrepreneurs in the field of marketing, especially regarding modern marketing tactics and strategies, as well as the lack of an integrated approach to the strategy of promotion and development of the company.
\end{abstract}

Keywords: digital marketing, small and medium interprises.

Utilizarea strategiilor moderne de marketing de întreprinderile mici și mijlocii (IMM) prezintă un factor important care poate contribui la consolidarea activității de antreprenoriat, la modificări structurale calitative ale IMM-urilor, la durabilitatea și stabilitatea afacerii. Revoluția digitală și tehnologia oferă oportunităti noi pentru sectorul de antreprenoriat prin îmbunătățirea calității de comunicare cu clienții, iar marketingul digital (MD) este un instrument important ce poate asigura creșterea competitivității și eficienții acțiunilor întreprinse pentru promovarea produselor și serviciilor. În acest articol sunt prezentate rezultatele cercetării calitative privind percepțiile și practicile IMM în domeniul MD, realizat de către autor în anul 2019. Au fost intervievați 20 de antreprenori - proprietari ai IMM-urilor cu sediul în mun.Chișinău. Analiza include, de asemenea, un studiu de caz al practicii companiei BRAVO-MOTORS SRL. Baza teoretico-conceptuală a cercetării au constituit teoria contemporană a marketingului, abordarea bazată pe resurse (Resource-Based View, Wernerelt B.), teoria capacităților dinamice (Theory of dynamic capabilities, Teece et al.). Rezultatele cercetării au demonstrat că IMM nu acordă o atenție cuvenită digitalizării proceselor de afaceri, colectării și analizei datelor, optimizării proceselor de muncă și controlului indicatorilor cheie. Rolul și importanța dezvoltării unei strategii de marketing în multe cazuri sunt subestimate, activitățile de marketing limitându-se la utilizarea doar a unor elemente de marketing. S-a constatat un nivel scăzut de competență a antreprenorilor în domeniul marketingului, în special privind tacticile și strategiile de marketing modern, precum și lipsa unei abordări integrate a strategiei de promovare și dezvoltare a companiei.

Cuvinte-cheie: marketing digital, întreprinderi mici și mijlocii.

Использование современных маркетинговых стратегий для малых и средних предприятий (МСП) является важным фактором, способствующим укреплению предпринимательской 
активности, качественным структурным изменениям МСП, обеспечению устойчивости $u$ стабильности бизнеса. Цифровая революция и технологии открывают новые возможности для предпринимательского сектора, улучшая качество связи с клиентами, а диджитал-маркетинг (ДМ) является важным инструментом, который может обеспечить конкурентоспособность и эффективность действий, предпринимаемых для продвижения продукции и услуг. В данной статье представлены результаты качественного исследования восприятия и практики МСП в области ДМ, проведенного автором в 2019 году. Было проинтервьюировано 20 предпринимателей - владельцев МСП в г. Кишиневе. Исследование также включает анализ практики компании BRAVO-MOTORS. Tеоретикоконцептуальной основой исследования послужили современная теория маркетинга, ресурсный подход (Resource-Based View, Wernerelt B.), теория динамических способностей (Theory of dynamic capabilities, Teесе et al.). Результаты исследования показали, что МСП не уделяют должного внимания цифровизации бизнес-процессов, сбору и анализу данных, оптимизащии рабочих процессов и контролю ключевых показателей. Роль и важность разработки маркетинговой стратегии во многих случаях недооцениваются, а маркетинговая деятельность ограничивается использованием лишь отдельных маркетинговых элементов. Наблюдается низкий уровень компетентности предпринимателей в области маркетинга, особенно касающихся современных маркетинговых тактик и стратегий, а также отсутствие комплексного подхода в стратегии продвижения и развития компании.

Ключевые слова: диджитал-маркетинг, малые и средние предприятия.

\section{RESEARCH PROBLEM}

Although the development Strategy of small and medium-sized enterprises sector for the years 20122020 aim to move from economic development model based on consumption, to a new one based on export, investment and innovation-oriented paradigm, of the political desire for European integration and of the global economic trends, so far, this has not been achieved at the expected level. Despite the overall creation of a more favorable environment for the entrepreneurial activity, the specific aspects regarding the capacity of the SMEs themselves to develop and strengthen their managerial and marketing activity enjoy very little of the policy makers attention.

In recent years, the competition among SMEs in the Republic of Moldova has increased considerably, this fact, to a large extent, being determined by the small retail market, as well as reduced opportunities to enter the international market. The statistics on SMEs show a considerable number of companies that stop their activity due to bankruptcy (BNS 2019).

From the perspective of the development of SMEs in the Republic of Moldova, in the short term, we can see the existence of multiple problems related to the insufficiency of the financial sources and qualified staff, fluctuation of the cadres, accounting and taxation, administrative barriers, etc. However, in the long term, the priority belongs to the requirements of the market, namely to strengthen the competitive capacities of small and medium-sized businesses, to integrate into the European space by using efficient marketing tools, especially the digital one.

The existing challenges show that an important objective for SMEs is to strengthen their competitiveness. In this context, the selection of marketing methods and techniques for improving the degree of competitiveness and further development of SME constitute an important objective of their activity. Marketing development may contribute to the entrepreneurship activity's consolidation, qualitative structural changes of the SMEs, as well as the sustainability and stability of the business.

The digital revolution and technology offer important opportunities for the entrepreneurship sector by improving the quality of communication with customers, being the premise for increasing the competitiveness and efficiency of the actions taken to promote products and services. People can follow the offers anywhere, anytime, in a flexible and individualized context that is permanently accessible. Currently, digital technologies are a determinative for the business development and competitiveness of the company, and existing research shows that digital technology determines the growth of SMEs, through innovation and management capacity (Foroudi et al. 2017). In addition, digital marketing supports activities to increase the number of clients and to maintain them as permanent clients (Александровский, Казанькова 2015). Thus, DM allows companies to get closer to potential customers (Kannan \& Li 2017).

DM is a general term for the marketing of products and services, through digital channels for attracting and retaining customers, being customized and measurable through digital technologies, including web, e- 
mail, databases, mobile and digital phones. DM contribute to achieve marketing objectives through applying digital technologies and media (Chaffey 2016). DM is "an adaptive, technology-enabled process by which firms collaborate with customers and partners to jointly create, communicate, deliver, and sustain value for all stakeholders" (Kannan and Hongshuang 2017).

Often there is no distinction between DM and Internet marketing, although they differ significantly. DM incorporates Internet marketing, but is not limited to the Internet. For example, Internet marketing includes SEO, SEM, SMM, Web browsing, advertisement context and other channels that are available to the user only on the internet, while DM includes all of the above plus advertising and promotion through any digital medium outside the network. So, DM involves digital communication that is done both online and offline. Obviously, the advertisement in newspapers, flyers, classic TV and panels do not have the tangency with digital marketing. A panel with a QR code with a link to a web site is already the DM.

The main tools of the DM are: Digital Television and online radio; Advertising in online messengers, applications and games; SEO and SEM - search engine marketing; SMS and MMS delivery; SMM - Social Media Marketing - promotion in social networks; Contextual advertising, banner ads and tizzer ads; Messengers on the official site (JivoSite, Smartsupp); Email marketing; Referral Marketing; VBM - Video Broadcast Marketing; Influences - collaboration with opinion leaders.

\section{RESEARCH GAP AND POSITIONING}

Most of researchers agreed that marketing plays a vital role in SMEs success, and helps them stay competitive, influence of marketing as a function of business needs to increase (Wymbs 2011). Entrepreneurial marketing uses networking to build and support marketing activity is based on the use and development of marketing management competencies and tries to be innovative where it can (Gilmore 2011).

Nowadays SME couldn't afford to avoid an online presence. Digital technology increases the ability to respond positively to customer needs and, at the same time, improves customer-side operations. It has been illustrated that the use of DM brings important benefits to companies, despite a small area of market. DM focuses on the consumers and businesses and increase efficiencies by reducing costs (Gilmore and Carson, 2018; Александровский С.В., Казанькова 2015).

The marketing development of SMEs is based on the life cycle of the company, four stages in its evolution being highlighted: initiating the marketing activity; reactive sales; DIY (do it yourself) marketing approach and proactive integrated marketing (Gilmore 2011). In the initial phase, the marketing activity is reduced to the determination of the optimal functional characteristics of the product, the price and the delivery conditions. At this stage, clients are usually close to the owner of the company people or the persons involved in the business. Increasing the number of new customers and sales in the second stage forces the company to apply formalized marketing procedures and to expand its range of marketing tools used to inform new customers about the company's offer. In the third stage, there is a growing need to pay special attention to marketing and to increase the budget for the marketing activity. The particularity of marketing at this stage will be completely determined by the attitude of the business owner towards marketing. Therefore, success, as well as failure, will depend entirely on the business owner (Gilmore, Carson 2018). Finally, if the company continues to grow (fourth stage of development), it will be necessary to use proactive integrated marketing or professional marketing.

The study of marketing in new SMEs has shown that they are based on marketing concepts to a very small extent, they consider the needs and desires of consumers and their subsequent satisfaction compared to other types of companies (Gilmore 2011). Many highly successful enterprises have never had a formal marketing strategy. Instead, they stumble on their business formula and evolve it to suit market conditions. In many cases, SMEs are change oriented only because their business and existing market is small and so they have to grow to survive or remain profitable, meaning that change is unavoidable. SME owner-manager business decision making can be both opportunistic and reactive to environmental changes and is often incremental rather than risk oriented. $\mathrm{T}$ (Gilmore and Carson 2018).

Previous research has shown that SMEs don't use the full potential of the new digital tools and are therefore not deriving the benefits from the opportunities they provide (Taiminen and Heikki 2015). Although DM is a cost-effective, creating awareness and purchase intentions, many companies still find it challenging adopting DM as a marketing strategy (Iankova et al. 2019; Andersson and Wikström 2017; Alves et al. 2016; Siamagka et al. 2015). DM is still a quite new and technically difficult area to understand and implementation can be challenging for companies that lack resources or knowledge. 
Researches conducted in post-transitional countries show that most SMEs are characterized by "spontaneous" or "intuitive" marketing, proposing as a possible solution the development of marketing consulting services. The process to engage small business owners' in marketing activities is unplanned, informal, and employed with a bottom-up approach. Moreover, the implementation of different marketing activities is reactive in nature due to the dynamic business environment. Experts argue that customer awareness contributes to increased marketing efficiency, customer loyalty and cost optimization. An individual approach helps cross-communication, communication, and marketing effectiveness analysis (Александровский, Казанькова 2015; Сидорчук 2016; Халиков 2018).

The study realized in Romania emphasizes the importance of online presence and use of DM. In base of a case study are detailed all the steps taken by the SMEs in the process of assuring an online presence. The study shows wide opportunities for extracting, manipulation and analysis of data using digital platforms and DM (Pistol et al 2016).

In the Republic of Moldova, DM is insufficiently studied in SMEs. Existing research shows that majority of SMEs do not carry out any marketing activities (Magenta consulting 2017). In many cases, this situation is determined by misunderstanding the importance of marketing by the owners-managers of SMEs, considering that not all of them possess entrepreneurial capacities and a good part of them are "selfemployed".

Based on the above, we conclude that despite the various research interest, the knowledge about the ways in which SMEs actually undertake DM activities and what type of problems they face implementing DM remain limited.

\section{THEORETICAL BACKGROUND}

The research of SME practices in the field of digital marketing is based on several theoreticalconceptual approaches regarding the concept of marketing, the role of marketing in managerial activity.

The modern theory of marketing represents marketing activity as aimed at achieving the goals of the enterprise and ensuring its competitiveness. In conditions when it becomes impossible for the manager to accurately calculate the results of his activities, the marketing complex, with its own set of controlled variables, factors and tools, is used by the enterprise as a protective, responsive reaction to the created economic conditions of uncertainty and risk.

Market orientations conceptual approach emphasizes that the behavior of the firm revolves around that of the market. It is a set of behaviors and processes related to a continuous assessment environment (Matsuno et al. 2002).

A Resource-Based View (RBV) is a strategic management theory that helps assess how a firm's resources affect its financial performance. The Resource-Based View suggests that each organization possesses a distinctive set of resources and capabilities that help explain the variance in firm performance over time. The RBV focuses on internal strategic resources that align with the company's strategic intent and serve as the basis of competitive advantage. The underlying assumption of the RBV is that resources and capabilities possessed by firms are heterogeneous and imperfectly transferable (Wernerelt 1984).

Theory of dynamic capabilities. Dynamic capabilities theory examines a firm's ability to achieve and sustain a competitive advantage in a changing environment through reconfiguration and integration of its resources and capabilities (Teece at al 1997). DCT assumes that organizations with greater dynamic capabilities will outperform firms with fewer dynamic capabilities. The dynamic capabilities can lead to better organizational performance; however, companies achieve competitive advantage, not through the existence of dynamic capabilities but through their application and usage (Nedzinskas et al. 2013).

\section{PORPOISE OF THE STUDY}

Analysis of SME perceptions and practices in the field of digital marketing, highlighting strong and weak parties, elaborating proposals to improve the situation.

Data and methods. In order to study the knowledge, attitudes and practices of SMEs in the use of digital marketing in 2019, a qualitative sociological study was conducted, based on the semi-formalized interview method. Twenty entrepreneurs - owners of SMEs based in Chisinau with the number of workers from 5 to 15 were interviewed; the level of education of entrepreneurs: high; domain of activities: sales, software development, services, agriculture, advertising areas of activity.

A case study was also carried out based on the BRAVO-MOTORS small company (number of employees -6 persons, duration of activity - 10 years), which specializes in car repairs and sales of auto parts. 
The main research questions were: What is the level of digitalization of SMEs? What are the main marketing strategies of entrepreneurs? What digital marketing tools are used by entrepreneurs?

A database on the Microsoft Access platform was developed for data collection and analysis. This approach also presents a variant of digitizing the process, offering the possibility of registering the data directly into the database and further analysis.

\section{MAIN RESULTS}

Currently SMEs need information technologies for efficient functioning and continuous development. Thus, an important component of the SMEs' activity is the need to store and exchange information, automate accounting and other business processes. Performing these tasks leads to optimization and minimization of the company's transaction costs. A unique information system is required to integrate business applications into company`s management, which includes:

1) End-to-end automation of all the main business processes of a trading company

2) Inventory automation and warehouse operations, direct data entry from online cash registers

3) Inventory management automation, supply chains, logistics and transport

4) Financial management, budgeting automation, financial analytics

5) Personnel performance management automatization

6) Customer relationship management automatization

7) Cloud office applications and cloud services for work organization of geographically distributed personnel

8) Cloud communication services and virtual call centers

9) Accounting, tax and statistical accounting automation

10) Automation of the exchange of electronic documents and data with contractors and supervisory authorities.

The digitalization of processes within the SME presents an important premise for the development and implementation of the DM. The results of the research show that only 3 respondents out of 20 of those interviewed appreciate their level of digitalization of SMEs at a high level and another 4 - at medium level. Some of the entrepreneurs could not evaluate the situation in the field of their company's digitalization (8 persons). 4 respondents consider that the level of digitalization of the company is at a low level. It is remarkable that the proportion of entrepreneurs who evaluated the level of digitalization of the enterprise as low and those who could not answer this question coincides with the proportion of companies that so far carry operational records without the use of specialized software such as CRM or ERP (figure 1).

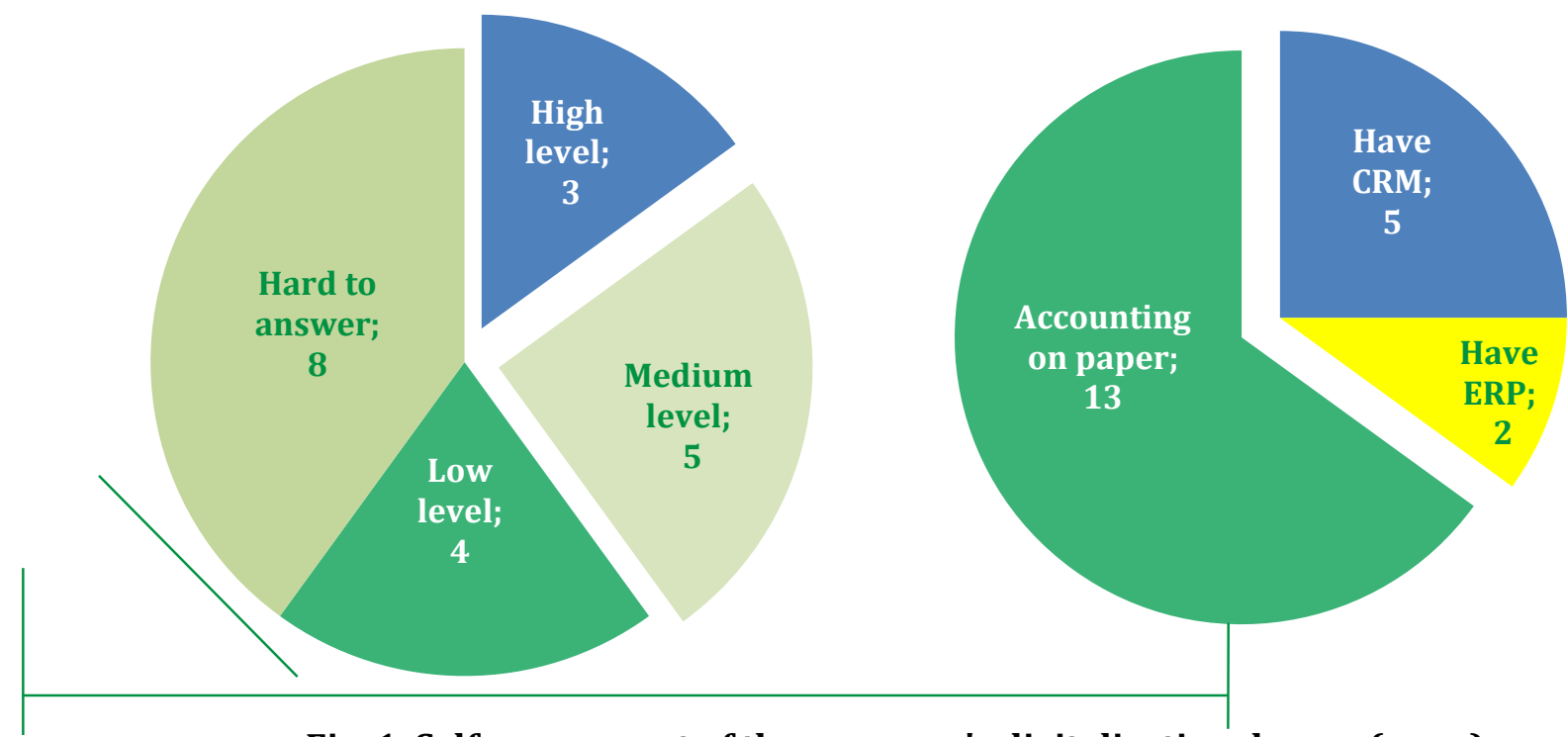

Fig. 1. Self-assessment of the company's digitalization degree (pers.)

Source: Own qualitative study, 2019. 
The research results showed that within the studied SMEs in most cases the marketing is the responsibility of the team members and / or the manager / owner. It means, the managers know best the particularities of the business and their niche activity. This approach of dealing with marketing on their own has both a positive and a negative aspect. On the one hand, any additional activity consumes extra time, respectively, no other important activities are performed. Involvement in all activities negatively influences the execution of the main activities as well as the quality of services and products offered by the company. On the other hand, no business can operate without promotion (figure 2).

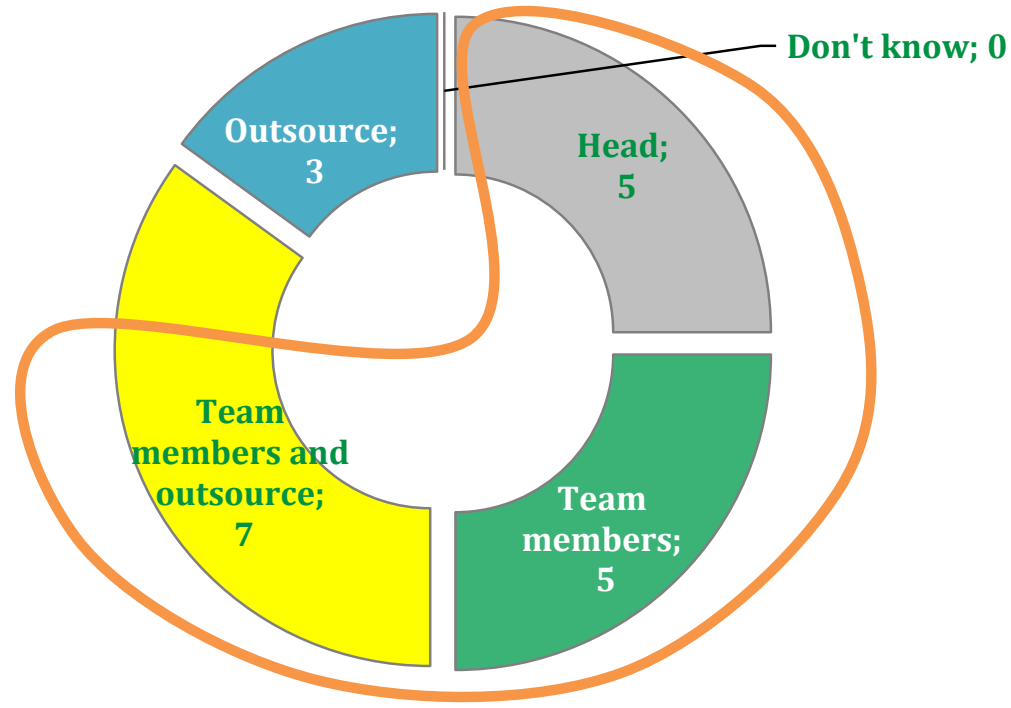

Figure 2. Staff involved in marketing activities (pers.)

Source: Own qualitative study, 2019.

An important aspect of the marketing activity presents the collection, systematization and analysis of the information regarding different aspects of the marketing activity. Obviously, most SMEs in the country do not have the financial resources to carry out or order marketing researches. An important issue arising from these is the ability of SMEs to analyze available information, collected by themselves, which should be the basis of managerial decisions. Respectively, the main sources of information are the internal ones: documents that record the sales and the revenues; customer requests; payment invoices; documents for returning the goods; customer complaints; financial reports etc.

The lack or availability of the tools required for data analysis does not always correlate with their use. In the study, the majority of the entrepreneurs stated that they analyze the structure of the customers and the sources of conversions. But after specifying the answers it was found that in most cases it is not about digital analysis, which is, concrete figures, but only estimates based on individual experience. As a result, we can see that a good part of the entrepreneurs do not carry out the necessary analyzes and do not have the necessary tools for this process (figure 3).

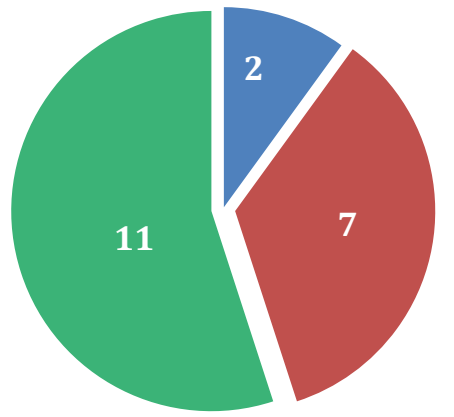

$$
\begin{aligned}
& \text { Yes } \\
& \text { No } \\
& \text { Would like to, but they don't } \\
& \text { have enough tools }
\end{aligned}
$$

\section{Figure 3. Distribution of answers regarding the analysis of customer} structure and conversion sources (pers.)

Source: Own qualitative stud, 2019. 
The biggest problem faced by SMEs in 2018 was the perception of marketing tactics and contemporary trends in promoting products and services. At the same time, there is a concern about maintaining customers and attracting them repeatedly to use the products / services provided by companies. According to the self-assessments of the respondents, the SMEs in which they operate did not take the marketing seriously (figure 4).

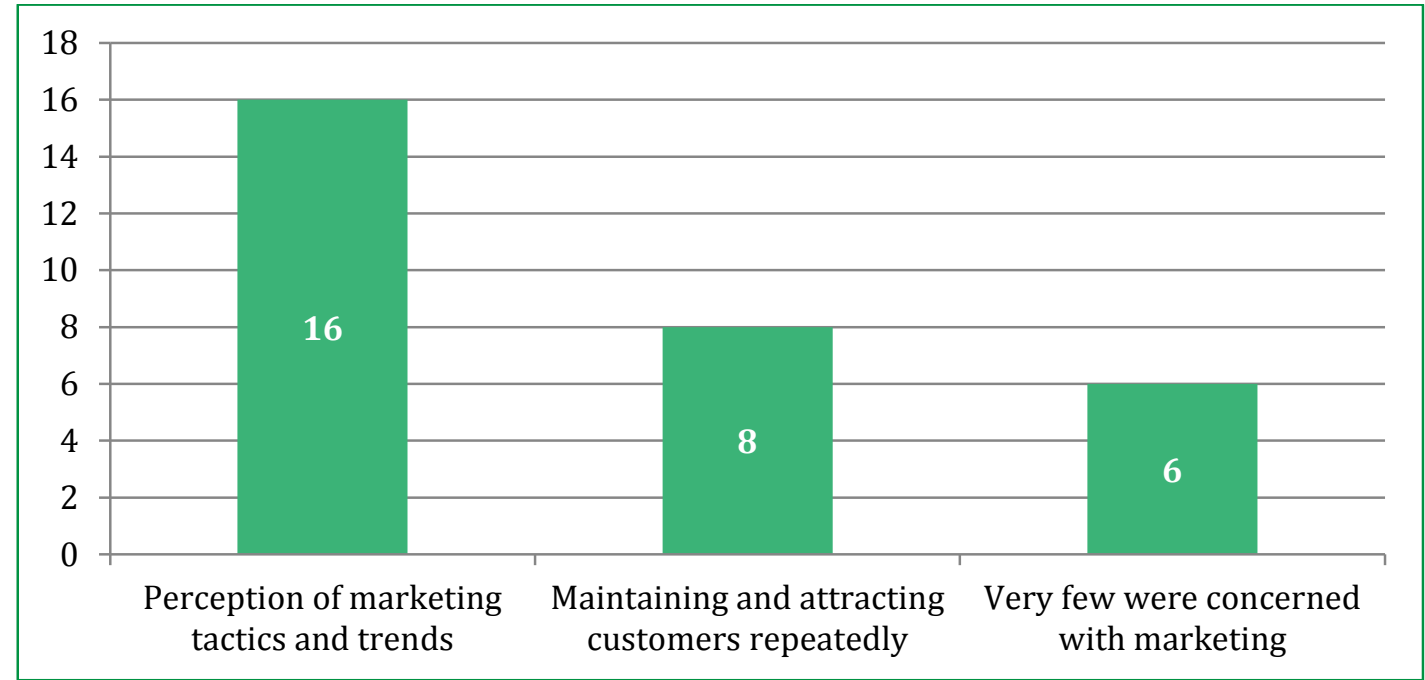

Figure 4. Marketing problems that entrepreneurs face (pers.)

Source: Own qualitative study, 2019.

Most of the studied companies have their own websites (2/3). This fact shows us that entrepreneurs understand the importance of their presence in the web and having their own independent platform in Internet space. However, most of them do not systematically promote websites and they remain invisible to potential consumers/customers. Any business requires promotion but unpromoted websites remain invisible for potential customers and are thus useless. Therefore, this digital marketing tool can be considered as not being used effectively and does not exercise the function of attracting customers and increasing profit.

To get higher search engine rankings websites need to be promoted using SEF, SEO and SEM technologies. In combination with relevant and unique content with a friendly interface, such a site can in the short term be ranked in the search results page list.

Search engine optimization (SEO) is the process of making a website rank for desirable keywords in order to bring in search traffic. SEO targets the factors search engines use to rank pages, including: site technical factors such as HTML titles, HTML tags, keywords, links, image alt text, website organization (everything from the sitemap to any redirects) and other factors help search engines determine what the site is about; Content quality and quantity; reputation: if your domain ranks well, and has links to other respected domains, it's easier to make individual pages rank; local factors (small businesses can rank higher in local searches. SEO helps search engines recognize a website as a local business).

However, SEF, SEO and SEM services are very expensive and decisions on such expenses must be made correctly. The promotion of the websites of companies of different sizes does not differ. So, promoting a website for a small company will cost as much as it does for a large company. In the Internet space all the sites are equal in competitiveness, the inequality only appears in the technical performance and the level of preparation for SEF and SEO. The budget of small businesses can't compare with the budgets of large companies and sometimes occupies a fairly large share of the SME profit.

So, even if online becomes very attractive for entrepreneurs, several regional characteristics of our country must be taken into account.

Case study. For Moldova, the main search engine for goods and merchandise for sale and purchase purposes is the 999.md platform. This means that a relevant online business-specific tool 
must be chosen. For example, during a period in the Republic of Moldova there were top SEO projects and several entrepreneurs invested their time and money in developing online commerce, which ultimately did not redeem themselves. For example, the BRAVO-MOTORS company invested 1000 euros and over 2500 working hours for the development of its own online trading platform. In the first 12 months of promotion, the company managed to appear on the top positions on the Page with the Google search engine results on high frequency search requests as "tires" and "car batteries", but this fact did not positively influence the sales volume of the company. on the categories indicated above. This situation changed only once, when in 2014 the 999.md platform did not function normally for 2 weeks and the traffic on the company website and the demand for products promoted through the official website of the company increased 5 times. After 999.md started operating as usual, the indicators dropped again. So, presence in what we call „search engines” is important, but it is not always a key to success. Thus, for different areas different approaches for offering data for search requests should be applied.

Presence on digital maps. Only half of the interviewed respondents found that their company is present on the digital map. This phenomenon can be explained in two ways - either half of the businesses do not have offline offices, or they do not consider the presence on the maps as an important criterion.

Video content. In recent years there has been a trend of increasing video publications. Here we can indicate that SMEs feel and adapt quickly to market trends and requirements. Out of 20 entrepreneurs interviewed 18 declared that they have regular video feeds. Thus, modern technologies and powerful electronic devices widely accessible offer the possibility of any individual to deal with filming, news and organizing their own video channel.

Summarizing the results of the qualitative study, we find that although the entrepreneurs are aware of the importance of the DM and the facilities offered by it, the marketing activities of the SME have a spontaneous, unorganized character and, to a large extent, depend on the skills of the owner in the IT and marketing fields. Most entrepreneurs do not collect and analyze statistics, they do not have a well-established marketing strategy.

At the same time, the study shows that the entrepreneurs - the owners of the SMEs face certain difficulties in incorporating the general marketing methods and procedures, as well as the digital marketing, in the activity of their enterprises. One of the main problems is that the marketing of SMEs, in most cases, is spontaneous. Limited resources and insufficient experience in studying the situation on the market determines that the marketing within the SMEs is executed by the owner and rarely selects the specialists in the field.

For many companies, especially SMEs at the consolidation stage, making the right marketing decision is very difficult, which influences the rate of revenue growth and the position of the SME on the market (business sustainability).

The specificity of marketing, including the digital one, in SMEs is determined by two main factors. First, by contacting SMEs, the client is in close action with the manager and business owner, which is not characteristic of large companies. This fact determines the availability of direct feedback from consumers of goods and services, allowing immediate decision-making for the current activity, compared to large companies, where the adoption of most decisions goes through a long negotiation phase. Mobility in decision-making when working with consumers has the advantage of small businesses, but the price of incorrect decision is higher.

Secondly, an important factor that determines the advantage of SMEs is the ability to constantly change and adapt quickly to new market requirements and conditions. Continuous competition for survival, proximity and dependence on buyers and suppliers, the need to constantly think about reducing costs and others does not leave the possibility that a small business is not concerned about its development. As a result, the issue of constant innovation, use and modification of marketing tools when working with consumers becomes a matter of "life and death" for SMEs. To a large extent this differentiates small businesses from large enterprises, where the implementation of any innovation almost always turns into a long-term process.

At the same time, most of the SMEs in the Republic of Moldova do not work online now. Customers visiting a store or office are more likely to use the "door" or phone to complete a purchase. 
Obviously, digital marketing can help a business grow, find new customers in the un-covered market segments.

The research shows that within the strategies that can be approached in the digital environment, it must start from defining the goals of the organization, established according to marketing research to identify the categories of consumers. Of a particular importance for the success of the business is the strategic vision of the entrepreneur, the development of the general strategy and the short and long-term marketing strategy, the identification of the specialized niches, etc.

\section{CONCLUSIONS AND RECOMMENDATIONS}

The results of the study showed that entrepreneurs do not pay serious attention to digitalization of business processes, data collection and analysis, optimization of work processes and control of key indicators. As a result, management decisions are made intuitively.

Many entrepreneurs continue to underestimate the role and importance of marketing and are limited to using only individual elements of marketing or, at best, its individual complexes. This means that the adoption and implementation of management decisions is carried out without marketing justification, which jeopardizes the stability and long-term business. Underestimation of the importance of marketing activities creates a significant risk, generates unreasonable solutions

Due to the lack of marketing strategy and resources the owners of SMEs tend to favor marketing activities that generate immediate or short-term results. SMEs are generally inclined to use traditional technologies instead of the updated ones, which are also cheap and easy to use, they do not use the full potential of the new digital tools, and so are not deriving benefit from the opportunities they provide.

The main problems identified based on the sociological study carried out, in the marketing activities of SMEs in the Republic of Moldova are the following:

- Low level of competence of entrepreneurs in the field of marketing

- Lack of data collection and analysis tools

- The impossibility of a qualitative evaluation of the marketing activities without an analytical database based on statistical data

- Lack of understanding of modern marketing tactics and strategies

- The use of DM technologies in a classical way, without analyzing the efficiency.

- Lack of quality management.

- Lack of managing the company's image on the Internet.

- Lack of an integrated approach to the company's promotion and development strategy.

Some of these problems are quite difficult to solve at the level of individual SMEs, which indicates the need to make changes to existing forms of support for small and medium-sized businesses at the institutional level. It is worth paying attention to the development of marketing support for SMEs, especially at the stage of formation.

Based on the study conducted, some recommendations for improving the marketing are proposed, including the DM strategies within the SME.

- SMEs need to pay greater attention to the digitalization of internal processes and the implementation of software as a basis.

- It is necessary to identify the profile of the target audience, the most efficient communication channels and the most promising business segments based on statistical (analytical) data.

- Increased competence of entrepreneurs in the field of marketing.

- The use of DM technologies, taking into account the technical capabilities of collecting the information they offer.

- Correct targeting, which does not aim at wide coverage, but at a higher quality point and quality.

- Develop a short-term and long-term strategy to promote the SME, its products and services.

- Comprehensive and consistent use of different communication channels.

- Managing the company's image on the Internet through Feedback.

Marketing trainings may help small business owners understand the importance of DM and increase their capabilities in using various tools. 


\section{REFERENCES}

1. BIROUL NAȚIONAL DE STATISTICĂ. Demografia întreprinderilor în Republica Moldova în anul 2018 [citat 27 martie 2020]. Disponibil: https://statistica.gov.md/newsview.php?l=ro\&idc=168\&id=6540

2. CHAFFEY, D. and ELLIS, C. F. Digital marketing. Strategy, implementation and practice. 6th edition. Pearson, 2016. 728 p. ISBN 978-1-292-07761-1.

3. FOROUDI, P., GUPTA, S., NAZARIAN, A., \& DUDA, M. Digital technology and marketing management capability: achieving growth in SMEs. In: Qualitative Market Research: An International Journal. 2017, no 20 (2), pp. 230-246. doi:10.1108/qmr-01-2017-0014.

4. GILMORE, A. Entrepreneurial and SME marketing. In: Journal of Research in Marketing and Entrepreneurship. 2011, vol. 13, pp. 137-145. ISSN 1471-5201 [citat 12 martie 2020]. Disponibil: https://doi.org/10.1108/14715201111176426

5. GILMORE, A., CARSON, D. SME marketing: efficiency in practice. In: Small Enterprise Research. 2018, vol. 25 (3), pp. 213-226 [citat 12 martie 2020]. Disponibil: https://doi.org/10.1080/13215906.2018.1521740

6. IANKOVA, S., DAVIES, I., ARCHER-BROWN, C., MARDER, B., \& YAU, A. A comparison of social media marketing between B2B, B2C and mixed business models. In: Industrial Marketing Management. 2019, no 81, pp. $169-$ 179 [citat 12 februarie 2020]. Disponibil: https://doi.org/10.1016/j.indmarman.2018.01.001

7. KANNAN, P.K., LI, H. Digital marketing: A framework, review and research agenda. In: International Journal of Research in Marketing. 2017, vol. 34 (2), pp. 22-45. ISSN 0167-8116

8. KANNAN, P.K. \& HONGHSUANG, A. 2017. Digital marketing: A framework, review and research agenda. International Journal of Research in Marketing, 34, pp. 22-45.

9. Magenta consulting [citat 12 martie 2020]. Disponibil: http://consulting.md/rom/statistici-sipublicatii/marketing-o-religie-noua-pentru-intreprinderile-din-republica-moldova

10. MATSUNO, K., MENTZER, J.T., OZSOMER, A. The effects of entrepreneurial proclivity and market orientation on business performance. In: Journal of Marketing. 2002, vol. 66 (3), pp. 18-32. ISSN 0022-2429.

11. NEDZINSKAS, S. et al. The impact of dynamic capabilities on SME performance in a volatile environment as moderated by organizational inertia. In: Baltic Journal of Management. 2013, vol. 8(4), pp. 376-396. ISSN 1746-5265 [citat 25 martie 2020]. Disponibil: https://doi.org/10.1108/BJM-01-2013-0003

12. PISTOL, Luminita \& EPURE, Manuela \& BUCEA-MANEA-TONIS, Rocsana. WEB-Marketing Strategy for SMEs. In: Procedia of Economics and Business Administration. 2016, no 3, pp. 128-137. ISSN 2392-8166.

13. TAIMINEN, Heini, KARJALUOTO, Heikki. The usage of digital marketing channels in SMEs. In: Journal of Small Business and Enterprise Development. 2015, vol. 22, pp. 633-651. ISSN 1462-6004 [citat 12 februarie 2020]. Disponibil: https://doi.org/10.1108/JSBED-05-2013-0073

14. TEECE, D.J., PISANO, G.P., SHUEN, A. Dynamic capabilities and strategic management. In: Strategic Management Journal. 1997, vol. 18, pp. 509-533 [citat 12 februarie 2020]. Disponibil: https://doi.org/10.1002/(SICI)1097-0266(199708)18:7\%3C509::AID-SMJ882\%3E3.0.C0;2-Z

15. WERNERFELT, B. A resource-based view of the firm. In: Strategic Management Journal. 1984, vol. 5, pp. 171180 [citat 12 februarie 2020]. Disponibil: http://web.mit.edu/bwerner/www/papers/AResourceBasedViewoftheFirm.pdf

16. WYMBS, C. Digital marketing: The time for a new "academic major" has arrived. In: Journal of Marketing Education. 2011, vol. 33 (1), pp. 93-106. ISSN 0273-4753.

17. ALEKSANDROVSKIJ, S.V., KAZAN'KOVA, N.V. Instrumenty digital-marketinga v praktike микро-, malogo i srednego biznesa. V: Marketing i marketingovye issledovaniâ. 2015. № 3, ss. 206-216. ISSN 2074-5095 [citat 27 martie 2020]. Disponibil: https://grebennikon.ru/article-85dt.html

18. SIDORČUK, R. Model' marketigovoj èkspertnoj sistemy v strukture poderžki malyh i srednih predpriâtij (Model marketing expert system in the structure of small and medium enterprises). 2016. [citat 12 februarie 2020]. Disponibil:

https://www.researchgate.net/publication/293133762_Model_marketingovoj_ekspertnoj_sistemy_v_stru kture_podderzki_malyh_i_srednih_predpriatij_Model_marketing_expert_system_in_the_structure_of_small_ and_medium_enterprises

19. HALIKOV, G.V. Predprinimatel'skij marketing: perspektivnye issledovanij. V: Izvestiâ Sankt-Peterburgskogo gosudarstvennogo èkonomičeskogo universiteta. 2018, no 2 (110), ss.162-168. ISSN 2311-3464.

\section{ARTICLE HISTORY}

Received 27 April 2020

Accepted 27 May 2020

No. $1 / 2020$ 